We begin by outlining the context of the research and by reviewing appropriate literature. We go on to describe the case study methodology adopted. Our overview of key thematic findings includes foci on the teachers' experiences of learning to read and of learning to teach reading and then on the actual teaching and learning of reading in the primary school and adult centre. We conclude with a discussion of the findings and recommendations arising from this.

\section{Context of research}

The school and adult centre are situated in a rural area about $20 \mathrm{~km}$ from Pietermaritzburg in the province of KwaZuluNatal, South Africa. The settlement is surrounded by sugarcane farms. Most employed residents commute to town by bus or taxi. According to the 2011 census figures on the local municipality, $34 \%$ of young people were unemployed and could be seen at the time of the research congregating on the dusty streets. The census indicated that levels of literacy were relatively low:

- of those aged 20 and older, $18.6 \%$ had no schooling

- while the primary enrolment rate was $89.9 \%$, only $12.4 \%$ had completed secondary schooling

- only $1.3 \%$ had higher education.

The majority of households had an income of less than R20 000 per year, with the figure reaching over $80 \%$ for those households dependent on agriculture (Statistics South Africa 2011). A protest by young people against poor service delivery during the period of research indicated their frustrations with unemployment, lack of infrastructure and poor living conditions.

The school was neatly kept with a flourishing garden; it was secure, disciplined and functioned comparatively well, having achieved the best results in the admittedly poorly performing municipality, which had a matric pass rate of just 20\% (Statistics South Africa 2011). The school had 23 teachers and 995 learners at the time of the research, a ratio of 1:43.3, with 23 classrooms and a computer laboratory. It was run by a fully constituted and functioning governing body. Although the school had a library corner in the staff room, the donated books were dusty, disused and mainly inappropriate for the learners at this school. The adult centre used the school premises after hours. It offered Adult Basic Education and Training (ABET) Levels 1, 2 and 4. It had about 20 learners and four educators, some of whom were also school teachers or parents of children at the school.

\section{Literature review}

Most South African children do not learn to read well. Although the ANA tests (Department of Basic Education 2014) show a marked improvement in scores for home language literacy for children across the grades between 2012 and 2014 , only $48 \%$ of grade 9 children achieved a literacy rate of $50 \%$ or more. In 2014 ANA tests in first additional language (which is English for most South African children), only $48 \%$ of grade 6 children and $18 \%$ of grade 9 children achieved more than 50\% literacy. Even these scores may be overoptimistic. In spite of radical changes in official policy and substantial investment in education since the end of apartheid, schools that were disadvantaged in that era still tend to perform extremely poorly, and their plight is disguised in national averages, which are boosted by marks obtained by children at traditionally privileged, wellresourced and high-performing schools (Spaull 2012). To illustrate, in the 2007 SACMEQ measures of grade 6 scores, only $57 \%$ of children at schools falling in the lowest wealth quartile could read and understand a simple text, while $96 \%$ of children at schools in the highest wealth quartile could do so, indicating the bimodality of the South African education system (Spaull 2012:7).

In its report on the 2014 ANA tests, the Department of Basic Education acknowledges that in grade 9:

- Many learners in both home language and first additional language struggle to respond to questions that require the use of their own words ... [and]

- Learners are unable to interpret a sentence or give an opinion when required (Department of Basic Education 2014:10).

Reasons for this may lie in educational practices and understandings that were developed in the era of apartheid and remain ingrained in the system. Even in schools that are now adequately resourced and effectively managed, learners' performance is in many instances stunted by limitations in teachers' understanding and capacity. A common finding in school-based research is that teachers simply do not have knowledge of effective reading pedagogies and, as a result, cannot teach reading effectively in spite of their efforts to do so (Taylor 2014).

This shortcoming cannot be blamed on the teachers themselves. A study of the teacher education programmes at the five most prominent institutions offering teacher education in the country shows that, while all of them seek to graduate effective teachers, there are significant variations among them in both theoretical and practical aspects of training and, alarmingly, that:

across all five institutions, there may be insufficient focus on equipping student teachers to guide IP learners to become proficient readers and writers/producers of texts in a range of genres and modes. In particular, little or no attention is given to reading pedagogies across the sample. (Taylor 2014:17)

Why there is not a concerted move by planners of teacher education programmes to close this glaring gap is difficult to understand, especially when evidence of South African learners' poor performance in literacy is repeatedly and sensationally trumpeted across the country in news reports (e.g. Coan 2014).

A possible legacy of literacy taught in missions, with the associated activity of reading the Bible aloud, is that teachers in Sub-Saharan Africa have traditionally tended to view 
reading as primarily an oral performance rather than a cognitive exercise in accessing meanings in text (Trudell \& Schroeder 2007). This, overlaid with the overt restriction on critical thinking and expressing opinions that characterised Bantu Education, has possibly shaped the approach of South African lecturers and teachers to learning and teaching (Nkabinde 1997). This could be the cause of the enduring difficulty in transforming the character of teaching and learning in our classrooms that was foreseen as early as 1997 by educationalists and still bedevils our education system (Msila 2014).

Current measures of reading such as the ANA tests require learners to understand the meaning that writers of texts intend to convey and to give their own responses to this meaning. This requires teachers to enable their learners to read so that reading becomes a process of:

- perceiving textual features and relating these to schemas of letters and words

- selecting some of these to convert to concepts

- integrating lexical, semantic and syntactic information in text to construct meaning

- comprehending what the writer intended to say

- relating what is understood to what has been previously read and understood

- predicting the content of the text beyond the part currently in view

- recognising how elements of the information relate to each other and which are the most important

- monitoring one's own comprehension and strategising about what to do to fill gaps or resolve ambiguities (Grabe 2009; Reichle, Warren \& McConnell 2009).

Readers who are expected only to read aloud with acceptable pronunciation and a degree of fluency can be seen to succeed with only the first three of these components of the reading process. As Allington (2014:16) points out, overemphasis on oral reading speed results in 'students who can read aloud faster and more accurately but whose silent reading comprehension has not improved'. The development of oratorical reading skills is within the reach of poorly trained reading teachers partly because these skills are simpler than those of reading with authentic cognitive engagement and because usually it is clear when a word has been read correctly or incorrectly. When readers are expected to respond to texts in their own words and offer opinions that might be mutually exclusive but equally acceptable, poorly trained teachers flounder.

It is likely that inadequately performing teachers of reading would fulfil their task better if they understood reading less in terms of readers' oral performance (what we term 'oratorical reading') and more in terms of readers' accumulation of information as they go through the reading process described above. A useful image for this gathering of information might be readers as travellers discovering the landscape they travel through, based on what they see, what they remember having seen and what this leads them to expect to see. The Landscape Model of reading (Rapp \& van den Broek 2005) describes an efficient reader gathering information from:

- text currently in view

- memory of information gained in text directly preceding that in view

- memory of information gained from the text read so far

- readers' existing knowledge outside the text, but relating to it.

Readers who gather information in this way as they read construct mental representations of the meaning contained in texts; as their reading improves, so does the accuracy of the mental representation. When they are able to critically evaluate the content of text in relation to information remembered from experience, or gained from other texts and other sources, they can be said to be competent readers.

\section{Methodology}

The study adopted a case study approach (Rule \& John 2011), as the first step in an envisaged action research project. The case was the local 'learning community', comprising the primary school and the adult centre. The focus within the case was reading practices, and the teaching and learning associated with these practices in the school and adult learning centre, as well as in the homes of adult and child learners.

The problem of poor reading performance was identified by teachers in an initial exploratory meeting with staff from both the adult centre and the school. Following this, the ultimate aim of the project as decided by the teachers and University of KwaZulu-Natal (UKZN) staff was to research reading in the school and adult centre in order to work with teachers in improving their teaching of reading for understanding. The seven students' research foci fell within the broad parameters of this project and included reading assessment (Nehal 2013), beliefs and practices of reading teachers (Nkosi 2012), parental involvement in children's schooling (Rajin 2013), life histories of teachers of reading (Sivnarain 2013), teachers' reading development strategies in relation to their readiness to implement the recently introduced Curriculum and Assessment Policy Statement (CAPS) (Mather 2012), reading development of adult learners (Pillay 2013) and reading practices in the home (Mkhize 2012). In order to act on the findings of the study, a process of continuing feedback and training sessions were put in place with teachers at the school and adult centre. An enabling factor was that one of the teachers was an M.Ed. student on the research team. These measures allowed for a close collaboration between the research team and staff.

A range of methods of data collection was used by the data collectors involved in this project. They included interviews with the school principal, 6 school teachers, 3 ABET teachers, 3 ABET learners, 10 parents and 1 ABET District Subject Advisor; focus groups with 8 parents; home visits with 
TABLE 1: Focus, sources and methods of constituent studies.

\begin{tabular}{|c|c|c|c|}
\hline Study & Focus & Sources & Methods \\
\hline Mather (2012) & $\begin{array}{l}\text { Reading development strategies of Intermediate Phase } \\
\text { language educators }\end{array}$ & $\begin{array}{l}\text { - } 3 \text { Intermediate Phase teachers } \\
\text { - IP reading lessons }\end{array}$ & $\begin{array}{l}\text { - Interview } \\
\text { - Classroom observation }\end{array}$ \\
\hline Mkhize (2012) & $\begin{array}{l}\text { Role of the learning family in developing a reading culture } \\
\text { among adults and children }\end{array}$ & $\begin{array}{l}\text { - } 2 \text { families with parents at ABET centre and } \\
\text { children at school } \\
\text { - Home visits }\end{array}$ & $\begin{array}{l}\text { - Interviews } \\
\text { - Observations }\end{array}$ \\
\hline Nehal (2013) & Reading assessment in the grade 4 classroom & $\begin{array}{l}\text { - Grade } 4 \text { English teacher } \\
\text { - School Principal } \\
\text { - } 45 \text { grade } 4 \text { reading lessons } 4 \text { learners' exercise books }\end{array}$ & $\begin{array}{l}\text { - Interview and questionnaire } \\
\text { - Classroom observation } \\
\text { - Document analysis }\end{array}$ \\
\hline Nkosi (2012) & Teaching beliefs and practices of $A B E T$ teachers of reading & $\begin{array}{l}\text { - } 3 \text { ABET teachers } \\
\text { - ABET lessons }\end{array}$ & $\begin{array}{l}\text { - Interview } \\
\text { - Classroom observation }\end{array}$ \\
\hline Pillay (2013) & Reading development of Level 4 ABET learners & $\begin{array}{l}\text { - } 3 \text { ABET Level } 4 \text { learners } \\
\text { - ABET District Subject Advisor } \\
\text { ABET lessons }\end{array}$ & $\begin{array}{l}\text { - Interview and focus group } \\
\text { - Interview } \\
\text { - Classroom observation }\end{array}$ \\
\hline Rajin (2013) & The nature of parental involvement in the school & $\begin{array}{l}\text { - } 8 \text { parents of children at the school } \\
\text { - School documents } \\
\text { - School visits }\end{array}$ & $\begin{array}{l}\text { - Focus groups and interviews } \\
\text { - Document analysis } \\
\text { - Field observation }\end{array}$ \\
\hline Sivnarain (2013) & A life history study of two English language educators & $\begin{array}{l}\text { - } 2 \text { Senior Phase language educators } \\
\text { - SP reading lessons }\end{array}$ & $\begin{array}{l}\text { - Interviews } \\
\text { - Classroom observation }\end{array}$ \\
\hline
\end{tabular}

ABET, Adult Basic Education and Training.

2 families involved in the school and ABET centre; site observations; classroom observation of Intermediate Phase, Senior Phase and ABET lessons; and document analysis of learners' exercise books and school documents. Researchers conducted continuing qualitative thematic analysis of the data, which in turn informed further data collection. A summary of the foci, sources and methods of each study is presented in Table 1.

This particular article drew on a cross-cutting analysis of the students' work, identifying four key themes: teachers' experiences of learning to read, teachers' experiences of learning to teach reading, the teaching of reading in the primary school and adult centre, and reading in the home environment.

\section{Ethical considerations}

The research project proposal was scrutinised and approved through the UKZN Ethics Committee process. Permission was obtained from the school principal and centre coordinator, as well as from the provincial Department of Education. The project observed principles of informed consent in explaining the research project to participants in English or isiZulu, according to the participant's preference and advising them that participation was voluntary and that they were free to withdraw at any time. It also protected their anonymity by withholding the name of the school and centre and allocating pseudonyms to individual participants. The principles of non-maleficence and beneficence were also observed in feeding back findings to the participants and arranging workshops to address challenges arising from the research. Each student followed ethical principles in gathering data for their own study, as well as for the project as a whole.

\section{Findings}

\section{Teachers' experiences of learning to read}

Teachers had different experiences of learning to read. In some of their homes, parents read newspapers and books, thus modelling reading, and in others, they did not (Mather 2012). Although none attended a formal pre-school, some were read to at home by parents or older siblings, which gave them an advantage: 'they [parents] monitored my reading so when I went to school I was ahead of my peers' (Nehal 2013:76). One teacher was taught to read and write vowels and to count from 1 to 5 by his mother, a nurse, before going to school (Nkosi 2012:69; Sivnarain 2013:54). In some homes, although literacy practices were not sophisticated, and although the children did not go to well-resourced schools, a high value was placed on literacy (Sivnarain 2013). However, most encountered reading for the first time at school: 'There was no support at home because my mother had to move away for work reasons and I lived with my grandmother who could not read or write' (Nehal 2013:76). Haphazard but possibly useful support sometimes came from other children: some teachers remember regularly playing a game they called 'teacher and learners' where one child would pretend to be a teacher and teach younger children things they had learned in school (Sivnarain 2013).

All teachers experienced the teaching of reading at school in a similar way. Reading was taught using alphabetic and syllabic approaches through a bottom-up synthetic process of learning letters, linking them with sounds and combining them to make words. As one teacher put it: 'consonants with vowels were the basic e.g. ma me mi mo mu' (Nkosi 2012:78). Reading was assessed as reading aloud, and marks were allocated for individual oral reading performance. This was based not on comprehension of the passage, but on fluency and pronunciation. There was no written assessment of comprehension of reading. Reading was about memorising sounds and decoding words. One educator remembered being 'taught a song about the letter names of the alphabet to assist with memorising' (Nkosi 2012:73) and this extended to later grades:

Rote learning was the preferred method of learning. [The educator] talked about poems and history notes that they were able to recite at length without having any understanding of what they actually meant. (p. 73)

Another educator stated that they were not taught how to analyse a text critically: 'In fact we are just supposed to vomit what we have been taught' (Mather 2012:70). 


\section{Learning to teach reading}

Besides the formative experiences of being taught how to read at home (some) and at school (all), some teachers also encountered, albeit unevenly, teaching of reading at tertiary level, whether this was at a teacher training college, University of South Africa distance learning courses or a fulltime university, as well as at an in-service training level through workshops run by the Department of Education or Non-Governmental Organisations (NGOs). One educator felt that he was 'not adequately trained to teach reading' at college and learnt most of what he knew about teaching reading by attending in-service workshops (Mather 2012:71). Another reflected that 'not much training was given ... to teach children how to read' (Sivnarain 2013:49).

In these contexts, teachers learnt to use visual methods to teach reading, such as the use of flashcards, pictures associated with particular words and pictures in storybooks. The focus of meaning-making was on individual words in isolation rather than on larger segments of texts such as sentences or paragraphs or the text as a whole (Mather 2012). From in-service workshops, they learnt to draw on supplementary materials, such as the newspaper supplement Learn with Echo and its cartoon story Mkhize. However, teachers did not develop a consistent and comprehensive understanding of teaching reading. This resonates with Taylor's (2014) finding that teachers lack knowledge of effective pedagogies to teach reading.

Teachers understood from their training and from curriculum documents that comprehension was an important aspect of reading. However, few were able to translate this understanding into pedagogical strategies and activities in the classroom.

Regarding the adult educators, the ABET Subject Advisor indicated that 'few educators know how to teach reading' because they had not been trained to and lacked the relevant skills. They were not able to link reading to speaking, listening and writing (Pillay 2013:49). This was confirmed by lesson observations of adult classes.

\section{Teaching of reading}

On the whole, instruction of reading, both in the school and the adult centre, reflected the teacher's beliefs about reading as the decoding of visual symbols and an oral process of reading aloud. This took the form of the teacher modelling reading aloud for the children, with particular attention to pronunciation and fluency, and then asking learners to read aloud either in groups or as a class:

Sometimes I can read and then ask them to read ... and then I will tell them, 'You were supposed to read like this and this word you were supposed to pronounce it'. (Mather 2012:71)

Teachers of adult learners also saw themselves as models of reading with an emphasis on accuracy and correct pronunciation: 'As soon as learners made mistakes [the teacher] swiftly stopped them and corrected the words that were not properly pronounced' (Nkosi 2012:74). Observations of reading classes revealed similar patterns: the teachers follow the directions in the CAPS document as they understand them, doing 'shared reading', which usually takes the form of reading a short text aloud to the class and then getting the class to repeat that and 'group guided reading, where children read the story aloud to each other'. No practice or guidance in silent reading took place, and in the school classrooms, there was almost no guidance with understanding beyond the level of single words (Mather 2012; Sivnarain 2013). For formal assessment, individuals read aloud to the teacher. Little or no written work took place in preparation for or in response to reading. Teachers further indicated their understanding of reading primarily as decoding by identifying the main problem that their learners experience as 'pronunciation' (Mather 2012). Observation of adult classes indicated that learners were able to 'read fluently without experiencing problems decoding the words' but 'lacked the skills to fully comprehend' the text (Pillay 2013:43). The educator seemed to 'kill interest in the text by getting learners to read the passage repeatedly' (Pillay 2013:48) without getting them to engage in the contextual meaning of the text and its relation to their prior knowledge.

While these emphases on decoding, accuracy, pronunciation and oral performance were the rule, there were exceptions. One of the adult educators emphasised the importance of understanding reading both in his expressed beliefs about reading and in his actual teaching of reading. He understood reading as a meaning-making activity: 'I think for readers it is simply reading words and understanding what they are reading about' (Nkosi 2012:71). He used strategies such as asking learners questions about the text they had read, getting learners to discuss texts among themselves after they had read them, engaging in dialogue with learners about texts and giving them worksheets 'where they had to apply the information that they extracted from the text'. He also emphasised the importance of understanding the perspective of the writer and being able to 'read between the lines'. This was the same educator whose mother had taught him to read before he went to school and who was busy with postgraduate studies on adult education.

Regarding reading resources, while the school had some resources such as readers and textbooks at the appropriate level, it experienced shortages of materials: two or more learners typically shared a textbook. The adult centre, on the other hand, had virtually no resources appropriate for adults. One adult educator used a grade 6 children's reader for her ABET Level 4 class. Others wrote notes on the board from school textbooks. The ABET Subject Advisor confirmed the paucity of materials: 'There is not much channelled to the Learning and Teaching Support Material (LTSM)' (Pillay 2013:44). This meant that the Unit Standard 'learners must be able to read and view a number of different texts developed for different purposes, audiences and contexts' could not be achieved. 
In general, however, teachers of both children and of adults used the same methodology to teach reading that was used by their teachers to teach them at primary school, with a few modifications based on what they had come to know about the coming CAPS directives and some reading teaching strategies they had learnt later. Besides the exception mentioned above, even teachers who professed a belief in reading as understanding did not teach reading comprehension. This indicated a tacit belief that 'as long as learners can pronounce words accurately it meant that they were able to read' (Nkosi 2012:76).

\section{Reading in the home environment}

The studies pointed to the critical role of parents as the 'first teachers' of their children and as exemplary readers (Desmond 2004). Many children at the school came from homes that had no or minimal reading materials: 'Old newspapers and adverts are the only thing our children can read', said one mother. A father reported reading 'hymn books that we use in church' to his children (Rajin 2013:71,73). Adult learners indicated that helping their children with their homework and understanding written communication from the school, for example, invitations to meetings, and information about and consent for school excursions, were part of their motivation for learning. It is heartening to note that, in spite of the problems described in this paper, they did make real progress. As one adult learner put it, 'Now I can ... teach my children how to write the homework at home ... or to read something or read a book' (Pillay 2013:54). They felt able to communicate with their children's teachers by writing notes to them. They felt more confident about attending school meetings, talking to teachers and reporting back to their children on what was discussed. Adult learners also reported being able to pass on information from pamphlets about health issues (TB or cholera) obtained from the clinic to their families and to read the Bible to them.

Mkhize's (2012) study of 'learning families' with children at school and parents attending the adult centre confirmed the value of family reading activities. The Foundation Phase children of adult learners spoke very positively about their parents' learning: 'I feel very excited because they set an example that we must go to school to learn and pass and be successful. They encourage me to learn' (Mkhize 2012:63). They referred to the family - parents and children - sitting together at home and doing their homework: 'When someone is having a difficulty with something, he asks someone for help ... We help each other'. Parents reading at home motivated their children to read: "They also want to read," an adult learner said of her two pre-school children' (Pillay 2013:55).

It is well worth noting that the children found reading at home much more enjoyable than reading at school. Although these children did not have books at home besides the textbooks they brought from school, they read newspapers that their parents sometimes brought home and the Bible and hymn books. This study indicated that there was more emphasis on real comprehension at home than at school.
As one mother said about stories that she read to her children: 'We discuss the details, the feelings and what would I have done ... They discuss what they have read, and I ask them questions and they explain where they can'. And another mother: 'We discuss our understanding of the text; we discuss and share the word of God' (Mkhize 2012:90-91).

\section{Discussion}

Grabe (2009) states that reading is most importantly a comprehending process, and comprehension is the basis for readers' accumulation and synthesis of information in the Landscape Model of reading described above. Yet the evidence from observation of reading classes in the school and adult centre indicates that this aspect was given the least attention compared to aspects such as decoding and pronunciation, with written comprehension given virtually no attention. This clearly resonates with the way teachers were themselves taught to read through a synthetic, bottomup process of moving from consonant and vowels, to syllables, to words, sentences and larger texts, largely through oral performance.

This indicates a generalised pedagogical understanding of reading as oral, decoding, primarily in groups or classes, with attention to accurate pronunciation. Classroom assessment rewards oral performance that demonstrates the ability to decode accurately and fluently, with scant attention devoted to the learners' ability to comprehend the text and construct a mental representation of its meaning. Given these emphases, it is not surprising that learners struggle with comprehension questions in the ANA tests. Of course, decoding is an essential part of reading, and accuracy and fluency are important attributes of competent reading, but if these are not linked to comprehension, they have little value outside of a particular kind of classroom-based performance genre. This kind of oratorical reading, which divorces form from meaning and decoding from comprehension, does not enable learners to engage in authentic reading, which always involves making sense of texts.

The strong link between the way that teachers were taught to read and the way that they teach reading suggests that there is a cycle of oratorical reading reproduction that continues to undermine learning to read and reading to learn in school and adult centres in South Africa (see Figure 1).

As indicated in our literature review, this oratorical 'plot' of teaching reading is widespread in our education system (Pretorius 2014; Verbeek 2010) and is not effectively 'replotted' in the training of teachers on how to teach reading in our higher education system (Taylor 2014). This is not a virtuous circle but an educationally emaciated and emaciating cycle, which is a consequence of the deliberate emphasis of apartheid era education on unquestioning acceptance of presented form. It is based on a monotonous reading plot that, in the absence of a conscious replotting of teacher education, replicates itself from one generation to the next. Unless this self-replicating pattern is deliberately, vigorously 


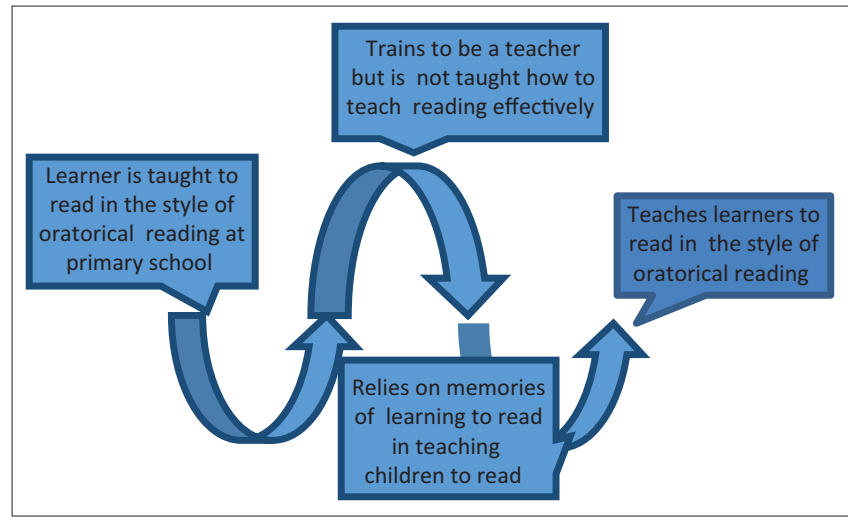

FIGURE 1: Cycle of reproduction of oratorical reading.

and intelligently transformed, South Africa will continue to occupy the bottom rungs of reading performance, with all the associated implications for further education, citizenship, employment, productivity and South Africa's profile as a learning nation.

\section{Finding the plot in reading education: Some pointers}

We need to devise deliberate strategies to break the cycle by paying explicit attention to redirect the way that we teach educators to teach reading and the way that we support reading in schools. We recommend that the following strategies are incorporated into the training of teachers of reading in South Africa:

- Teacher trainers should engage critically with educators' prior experiences and assumptions about teaching reading by raising questions such as: What does reading mean to you? How were you taught to read? What aspects of reading did your teachers see as important? What did you read at home and at school? One way of doing this is to get trainee educators to write a 'reading biography' in which they describe and reflect on their own history of reading and learning to read. They could then compare and evaluate experiences.

- Develop an understanding of all the elements of the reading process, recognising that decoding should lead to, and cannot replace, understanding of the text: 'Reading is, after all, about comprehension' (Pretorius 2014:68).

- Give teachers thorough training in effective approaches of how to teach reading, such as the 'Reading to Learn' methodology (Rose 2005), direct instruction and scaffolding techniques (Van Staden 2011).

- Create opportunities for educators to practice teaching reading in a supportive environment, including support in how to read to children. Reading materials used in training should be appropriate and accompanied by training, mentoring and monitoring in their use (Nassimbeni \& Desmond 2011).

- Use the practical teaching components of teacher training courses to give educators critical support and guidance in implementing effective reading teaching of reading strategies in a supportive environment.
- Create teachers' reading clubs in schools so that they can share their reading experiences and support each other's teaching of reading (Pretorius 2013).

- Equip educators to create a culture of reading in schools, supported at a district level, where reading is on the daily school agenda, through giving them a range of easy to implement strategies to make the most of 'Drop Everything and Read' periods, school libraries as transformational spaces for lifelong learning rather than merely depositories of books, incentives for reading a target number of books and establishing learners' reading clubs (Paton-Ash \& Wilmot 2015; Pretorius 2014; Pretorius \& Mampuru 2007).

- Explore creative ways of linking learners' home and school contexts; for example, through encouraging and supporting family literacy practices (Land 2005, 2011; Rule \& Lyster 2005), linking school reading to indigenous knowledge and oral traditions and involving parents and caregivers in school activities in culturally affirming ways such as gardening and planting projects (Ilima) and writing up traditional stories. In addition, parents should be encouraged to read aloud to their children at home (or older siblings could do so where parents are not literate), books that are enjoyable and not just educational should be read and a variety of fiction materials that draw the reader and listener in will inspire more interest in reading.

\section{Conclusion}

Drawing on a case study of reading at a primary school and adult centre in a rural KwaZulu-Natal community, this article has shown that an oratorical approach to the teaching of reading predominates in both settings; a finding that resonates strongly with reading research in other South African contexts. This oratorical emphasis is linked to teachers' own formative experiences of learning how to read, some of which were less than adequate. In order to address the ensuing limitations, a deliberate strategy to transform the way that teachers are trained to teach reading needs to be developed and implemented in teacher training programmes. This strategy should engage directly with teachers' prior experiences of and assumptions about the teaching of reading, model teaching processes that foreground comprehension, develop ways of supporting teachers in their teaching of reading in schools and adult centres and draw on the cultural resources of local communities.

\section{Acknowledgements}

The authors acknowledge the following Masters graduates whose studies contributed to this article: N. Mather, J. Mkhize, M. Nehal, I.N. Nkosi, A.E. Pillay, K.S. Rajin, R. Sivnarain and M. Shabane for their role. They also thank the principal, centre manager, teachers, parents and learners of the primary school and adult centre who participated in the study and made it possible.

\section{Competing interests}

The authors declare that they have no financial or personal relationship(s) that may have inappropriately influenced them in writing this article. 


\section{Authors' contributions}

P.R. and S.L. jointly designed and co-ordinated the overall research project, oversaw the data collection and analysis in the project, analysed the dissertations that provided the data for this article and wrote the manuscript.

\section{References}

Allington, R., 2014, 'Reading moves: What not to do', Educational Leadership 72(2), 16-21.

Chansa-Kabali, T., Serpell, R. \& Lyytinen, H., 2014, 'Contextual analysis of home environment factors influencing the acquisition of early reading skills in Zambian families', Journal of Psychology in Africa 25(5), 410-419.

Coan, S., 2014, 'Claims of mass test rigging', The Witness, 8 September, p. 1.

Department of Basic Education, 2014, Report on the annual national assessment of 2014: Grades 1-6 and 9, Department of Basic Education, Pretoria.

Desmond, S., 2004, 'Literacy for now and for the future: Working with parents and children', Language Matters 35(2), 348-362. https://doi.org/10.1080/ 10228190408566222

Draper, K. \& Spaull, N., 2015, 'Examining oral reading fluency among rural Grade 5 English Second Language (ESL) learners in South Africa: An analysis of NEEDU 2013', South African Journal of Childhood Education 5(2), 44-77. https://doi. org/10.4102/sajce.v5i2.390

Grabe, W., 2009, Reading in a second language moving from theory to practice, Cambridge University Press, New York City, NY.

Land, S., 2005, Family literacy: Bringing literacy home, DVD, Centre for Adult Education and Audio Visual Centre, University of KwaZulu-Natal, Pietermaritzburg.

Land, S., 2011, Family literacy: Baby steps to learning, DVD, Centre for Adult Education, and Audio Visual Centre, University of KwaZulu-Natal, Pietermaritzburg.

Machet, M.P. \& Tiemensma, L., 2009, 'Literacy environment in support of the development of literacy skills and voluntary reading', Mousaion 27(2), 58-76.

Mather, N., 2012, 'Making the CAPS fit: An exploration of the reading development strategies of three Intermediate Phase language educators in a rural KwaZulu-Natal school', MEd thesis, School of Education, University of KwaZulu-Natal, Pietermaritzburg.

Mkhize, J., 2012, 'The role of the learning family in developing a reading culture among adults and children', MEd thesis, School of Education, University of KwaZulu-Natal, Pietermaritzburg.

Msila, V., 2014, 'Critical thinking in open and distance learning programmes: Lessons from the University of South Africa's NPDE programme', Journal of Social Sciences: from the University of South Africa's NPDE programme', Journal of Soci
Interdisciplinary Reflections of Contemporary Society 38(1), 33-42.

Mullis, I.V.S., Martin, M.O., Foy, P. \& Drucker, K.T., 2012, PIRLS 2011 international results in reading, TIMSS \& PIRLS International Study Center, Boston College,
Chestnut Hill, MA, viewed from http://timssandpirls.bc.edu/pirls2011/ international-results-pirls.html

Nassimbeni, M. \& Desmond, S., 2011, 'Availability of books as a factor in reading, teaching and learning behaviour in twenty disadvantaged primary schools in South Africa', South African Journal of Libraries and Information Science 77(2), 95-103. https://doi.org/10.7553/77-2-52

Nehal, M., 2013, 'A study of reading assessment in the grade 4 classroom', MEd thesis, School of Education, University of KwaZulu-Natal, Pietermaritzburg.

Ngwaru, J.M., 2014, 'Promoting children's sustainable access to early schooling in Africa: Reflections on the roles of parents in their children's early childhood care
and education', in R. Serpell \& K. Marfo (eds.), Child development in Africa: Views and education', in R. Serpell \& K. Marfo (eds.), Child development in Africa: Views
from inside: New directions for child and adolescent development, vol. 146, pp from inside: New directions for child and ado
$61-76$, John Wiley \& Sons, New York City, NY.

Nkabinde, Z.P., 1997, An analysis of educational challenges in the New South Africa, University Press of America, New York.

Nkosi, I.N., 2012, 'An exploration of the teaching beliefs and practices of Adult Basic Education and Training teachers of reading', MEd thesis, School of Education, University of KwaZulu-Natal, Pietermaritzburg.
Paton-Ash, M. \& Wilmot, D., 2015, 'Issues and challenged facing school libraries in selected primary schools in Gauteng Province, South Africa', SA Journal of Education 35(1), 1-10. https://doi.org/10.15700/201503062342

Pillay, A.E., 2013, 'The reading development of level 4 ABET learners', MEd thesis, School of Education, University of KwaZulu-Natal, Pietermaritzburg.

Pretorius, E.J., 2013, 'The teachers' book club: Broadening teachers' knowledge and building self-confidence', Mousaion 31(1), 27-46.

Pretorius, E.J., 2014, 'Supporting transition or playing catch-up in Grade 4? Implications for standards in education and training', Perspectives in Education 32(1), 47-72.

Pretorius, E.J. \& Mampuru, D.M., 2007, 'Playing football without a ball: Language, reading and academic performance in a high-poverty school', Journal of Research in Reading 30(1), 38-58. https://doi.org/10.1111/j.1467-9817.2006.00333.x

Rajin, K.S., 2013, 'An investigation into the nature of parental involvement at a rural primary school', MEd thesis, School of Education, University of KwaZulu-Natal, Pietermaritzburg.

Rapp, D. \& Van den Broek, P., 2005, 'Dynamic text comprehension: An integrative view of reading', Current Directions in Psychological Science 14(5), 276-279. https:// doi.org/10.1111/j.0963-7214.2005.00380.x

Reichle, E.D., Warren, T. \& McConnell, K., 2009, 'Using E-Z reader to model the effects of higher-level language processing on eye movements during reading',
Psychonomic Bulletin \& Review 16(1), 1-21. https://doi.org/10.3758/ Psychonomic
PBR.16.1.1

Rose, D., 2005, 'Democratising the classroom: A literacy pedagogy for a new generation', Journal of Education 37(1), 131-168.

Rule, P. \& John, V., 2011, Your guide to case study research, Van Schaik, Pretoria.

Rule, P. \& Lyster, E., 2005, 'Keeping it in the family: Exploring relations between family literacy, early childhood development and adult basic education', in S. Land (ed.), Bringing Literacy Home: Family Literacy Conference Proceedings, Centre for Adult Education, School of Education, University of KwaZulu-Natal, Pietermaritzburg, September 19-21, pp. 3-11.

Sivnarain, R., 2013, 'Teaching reading: A life history study of two English language educators in a rural primary school in KwaZulu-Natal', MEd thesis, School of Education, University of KwaZulu-Natal, Pietermaritzburg.

Spaull, N., 2011, 'A preliminary analysis of SACMEQ III South Africa', Stellenbosch Economic Working Papers: 11/11, A Working Paper of the Department Of Economics and the Bureau for Economic Research, November 2011, University of Stellenbosch, South Africa.

Spaull, N., 2012, 'Poverty \& Privilege: Primary School Inequality in South Africa', Stellenbosch Economic Working Papers: 13/12, A Working Paper of the Department Of Economics and the Bureau for Economic Research, July 2012, University of Stellenbosch, South Africa.

Statistics South Africa, 2011, Mkhambathini, viewed 17 August 2015, from http:// www.statssa.gov.za/?page_id=993\&id=mkhambathini-municipality

Taylor, N., 2013, 'Dr Nick Taylor discussing the quality of SA education system', You Tube, May 7, viewed from https://www.youtube.com/watch?v=AzO-LI3POOY

Taylor, N., 2014, Initial teacher education research project: An examination of aspects of initial teacher education curricula at five higher education institutions. Summary report. JET Education Services, Johannesburg.

Trudell, B. \& Schroeder, L., 2007, 'Reading methodologies for African languages: Avoiding linguistic and pedagogical imperialism', Language, Culture and Curriculum 20(3), 165-180. https://doi.org/10.2167/Icc333.0

Van Staden, A., 2011, 'Put reading first: Positive effects of direct instruction and scaffolding for ESL learners struggling with reading', Perspectives in Education 29(4), 10-21.

Verbeek, D.C., 2010, 'Teaching reading for meaning? A case study of initial teaching of reading in a mainstream South African school', PhD thesis, School of Education, University of KwaZulu-Natal, Pietermaritzburg.

Zimmerman, L., 2014, 'Lessons learnt: Observation of grade 4 reading comprehension teaching in South African schools across the Progress in International Reading Literacy Study (PIRLS) 2006 achievement spectrum', Reading \& Writing 5(1), Art. \#48, 1-9. https://doi.org/10.4102/rw.v5i1.48 